\title{
INFLUENCE OF OZONE AERATION ON TOXIC METAL CONTENT AND OXYGEN ACTIVITY IN GREEN WASTE COMPOST
}

\author{
Maciej Gliniak', Łukasz Grabowski², Marta Wołosiewicz-Głąb², Daria Polek² \\ 1 University of Agriculture in Krakow, Department of Technical Infrastructure and Ecoenergetics Institute of \\ Agriculture Engineering and Informatics Faculty of Production and Power Engineering, Mickiewicza Av. 21, \\ 30-120 Krakow, Poland, e-mail: m.gliniak@ur.krakow.pl \\ 2 AGH University of Science and Technology, Faculty of Mining and Geoengineering, Department of \\ Environmental Engineering and Mineral Processing, Mickiewicza Av. 30, 30-059 Krakow, Poland, e-mail: \\ lukgrabo@agh.edu.pl,wolosiewiczm@gmail.com, polek@agh.edu.pl
}

Received: 2017.04 .29

Accepted: 2017.05.31

Published: 2017.07.01

\begin{abstract}
This paper presents the results of work on the reduction of toxic metal content while decreasing its oxygen activity. During the study the effects of different doses of ozone in the air used for aeration of the stabilized compost in the first post-thermophilic phase were analyzed. The results showed the possibility of reducing the concentrations of toxic metals and decrease the activity of oxygen by up to $30 \%$, compared to traditional stabilized compost aeration system without using ozone.
\end{abstract}

Keywords: compost, ozone, toxic metals

\section{INTRODUCTION}

The intensive socio-economic development that we observe in Poland causes an increase in the fraction of biodegradable waste. In accordance with applicable Polish law and EU guidelines called circular economy, a lot of efforts should be made to make the best use of raw materials which may be subject to the processes of recovery and recycling of waste. In Poland, material recovery is governed by the provisions of the Waste Act of December 2012 and the guidelines of the Department of Waste Management in the Ministry of Environment of December 2008. By analyzing the above documents, it was found that the main process of recovering biodegradable raw materials is composting [Grzesik and Malinowski 2016, Guidelines ... 2008, Dz. U. 2013 poz. 21, Ghiselliniet al. 2016, Morales et al. 2016].

In moderate climate conditions composting process is divided into two stages, with a total length of about 60 days. The duration of the process depends on the choice of the composting method (active system with aeration of material or passive without aeration) and the material to be processed. Based on the literature analysis of the subject, it was stated that the first stage of the composting process should take up to 14 days.

Then the material is subjected to stabilization, which lasts about 6 weeks. At present, the works on optimization of the composting process kinetics in the first phase and elimination of accompanying odor emissions in the whole process are carried out in the world. [Lebreroet al. 2011,Gutierezet al. 2015, Yuan et al. 2015, Fernándezet al. 2016, Jinyiet al. 2016, Sileset al. 2016, Yongjianget al. 2016].

Optimization of the stabilization phase of the obtained compost relates to the possibility of using various substances neutralizing additional impurities (e.g. toxic metals, petroleum products, etc.). The literature on the subject also describes the experience that refers to the hygienisation of stabilized compost and the possibility of using gases produced during the process. [Benlboukhtet al. 2016, Junyaet al. 2016, Lian et al. 2016, Mukeshet al. 2016, Vandecasteeleet al. 2016, Yuquanet al. 2016].

From a review of the subject literature, it appears that the major problem limiting the use of 
compost as a fertilizer is high concentration of pollutants - mainly toxic metals. Previous studies on the use of ozone in the composting process centered around the disposal of effluents [Ciesielczuk and Kusza 2009, Mokhtaraniet al. 2014, Amin et al. 2014].

In Poland, the possibility of using compost as a fertilizer is regulated by the Act on fertilizers and fertilization [Dz. U. 2007 No. 147, item. 1033], which classifies compost as an organic fertilizer. According to the guidelines of the Regulation of the Minister of Agriculture and Rural Development of 18 June 2008 on the implementation of certain provisions of the Act on fertilizers and fertilization, compost must meet strict quality requirements [Dz. U. 2009 No. 224, item. 1804].

Due to the lack of research and literature data, it was decided to investigate whether it was possible to use ozone as a substance that could reduce the toxic metal content and decrease the aerobic activity of the compost.

\section{MATERIALS AND METHODS}

The composting process was conducted in an isothermal bioreactor adapted for studies of biodegradable waste degradation processes (Figure 1). Based on laboratory research described in the literature [Kasiński and Wojnowska-Baryla 2013; Hurka and Malinowski 2015; Grzesik and Malinowski 2016] it was found that the course of the decomposition of organic matter in the bioreactor corresponds to composting processes on a technical scale. The study used a mixture of biodegradable waste consisting of grass $(50 \%)$, sawdust (25\%) and food waste (25\%) with a total fresh weight of $30 \mathrm{~kg}$.

The composition of the mixture was based on the literature data, to ensure obtaining the structural properties of the compost and providing a sufficient flow of air in the bioreactor, the biomass moisture content during the process (54-68\%) and $\mathrm{C}: \mathrm{N}$ ratio in excess of 20 units. For the correct composting process the air flow in the bioreactor was set at $0.035 \mathrm{~m}^{3} \cdot \mathrm{h}^{-1} \cdot \mathrm{kg}_{\mathrm{dw}}{ }^{-1}$ (calculated as the composted mass of waste is $0.4 \mathrm{~m}^{3} \cdot \mathrm{h}^{-1}$ ).

After the completion of the thermophilic phase of the composting process (reaching a material temperature of $45^{\circ} \mathrm{C}$ ), 3 representative samples of $1500 \mathrm{~g}$ material were collected from the bioreactor, stabilized with air at ozone levels of 0,10 and $20 \mathrm{mgO}_{3} \cdot \mathrm{dm}^{-3}$. Each representative sample was divided into 3 equal parts of
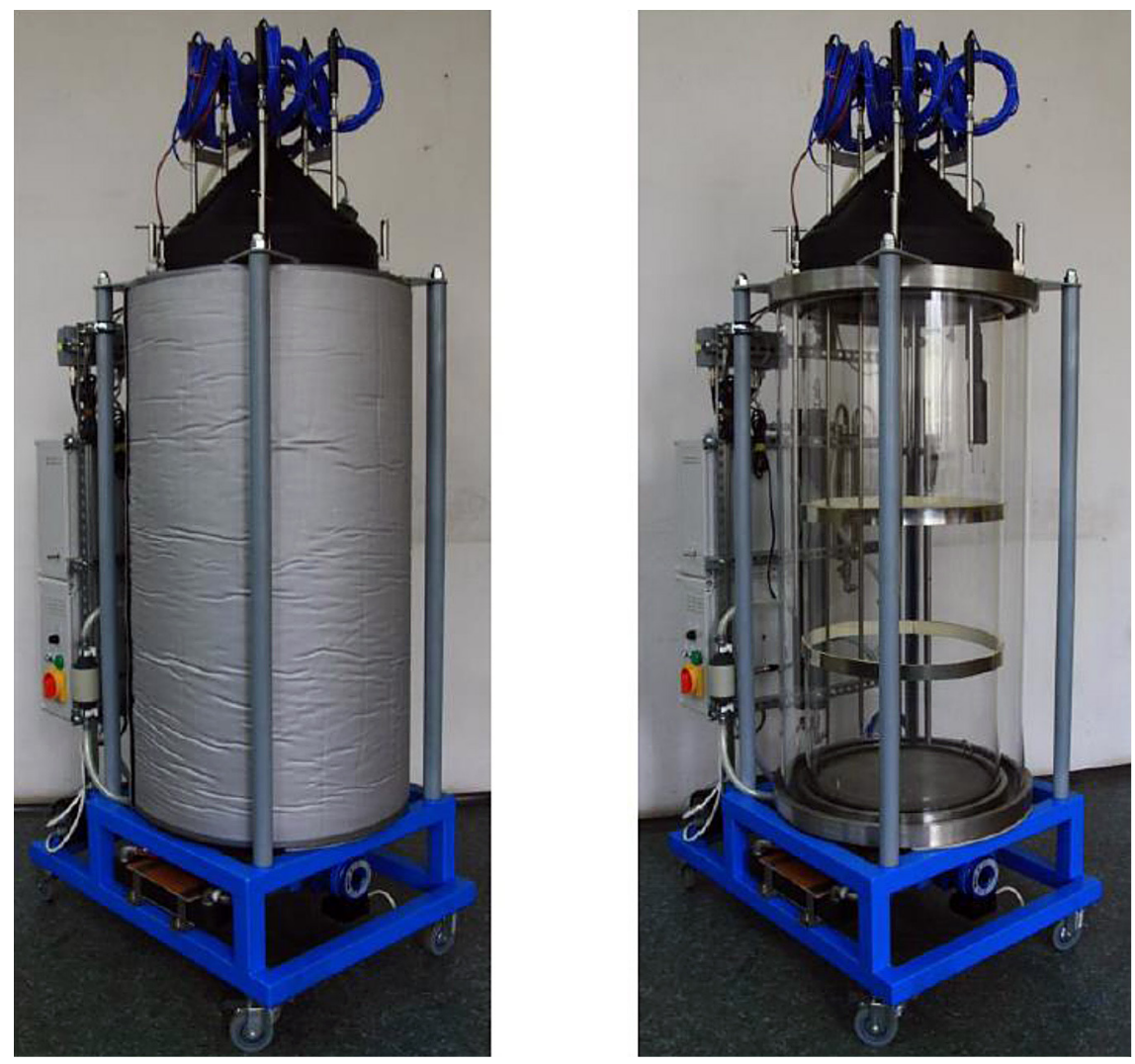

Fig. 1. Composting stand (photo: Rotameter, 2012) 
$500 \mathrm{~g}$ each, resulting in a total of 3 sets of ozone aeration samples. The ozone generator O3PRO DRP-30,7VW from Prozonex (Poland) was used to produce ozone-containing air. The aeration process was carried out in $500 \mathrm{ml}$ round bottom flasks equipped with an air diffuser located at the bottom. During the aeration, the flask was shaken in a LP-Shaker360 laboratory shaker. The sample aeration process lasted 1 day.

After completion of the stabilization process, lasting 16 days, the resulting compost was sieved through a sieve with a mesh of $2 \mathrm{~mm}$. The resulting material was mineralized in Milestone MLS1200 microwave oven. For the mineralization process, 3 sample weights of $0.25 \mathrm{~g}$ were prepared from each aerated compost sample. The samples were mineralized wet with $5 \mathrm{~cm}^{3}$ of a solution of aqua regia. The samples were digested using a microwave mineralizer according to the recommended mineralization program. The samples after mineralization were quantitatively transferred to $25 \mathrm{~cm}^{3}$ volumetric flasks using $1 \%$ $\mathrm{HCl}$ solution. The content of selected toxic metals $(\mathrm{Pb}, \mathrm{Cd}, \mathrm{Ni}, \mathrm{Zn}, \mathrm{Cr}, \mathrm{Cu})$ was determined by the atomic absorption spectrometer in a laboratory accredited to EN 13657: 2006.

From the obtained stabilization samples, 40 $\mathrm{g}$ of a sample was collected in 2 replicates to determine the aerobic activity of the material $\left(\mathrm{AT}_{4}\right)$ according to the Richtlinie für die mechanisch-biologische Behandlung von Abfällen. Analogous material samples were subjected to the moisture analysis according to PN-EN 15169: 2007.

\section{RESULTS AND DISCUSSION}

The content of selected toxic metals in the tested composter is shown in Table 1. The determined metal concentrations in the atmospheric air-borne ozone-free sample do not differ from the literature values for green waste compost obtained in household appliances [Lima et al. 2004, Madrid et al. 2007, Puglisi et al. 2007, Ciesielczuk and Kusza 2009]. The use of the additive of $10 \mathrm{mg} \cdot \mathrm{dm}^{-3}$ of ozone in the air at the beginning of the compost stabilization phase resulted in a $10 \%$ reduction in the content of $\mathrm{Pb}$ and $\mathrm{Cd}, 6 \%$ drop in the concentration of $\mathrm{Ni}$ and $\mathrm{Cr}$, and loss of $\mathrm{Cu}$ and $\mathrm{Zn}$ at 4 and $2.5 \%$ in relation to the compost aerated without ozone additive.

The addition of ozone at the level of 20 $\mathrm{mg} \cdot \mathrm{dm}^{-3}$ to the air during stabilization of the compost caused an increase in levels of the reduction of toxic metal concentrations in the samples. The greatest reduction was noted for zinc, which 3.5 times exceeded the removal of $\mathrm{Zn}$ for a dose of 10 $\mathrm{mg} \cdot \mathrm{dm}^{-3}$ of ozone. The lowest reduction of toxic metal content in the compost, with the application of $20 \mathrm{mg} \cdot \mathrm{dm}^{-3}$ ozone, is characterized by chromium and lead. The reduction of these metals in relation to the halftime of the ozone dose is 1.6 times. In other cases $(\mathrm{Cd}, \mathrm{Ni}, \mathrm{Cu})$ twice the increase in ozone in the air caused a double increase in the removal of toxic metals. Comparing the results of the reduction of toxic metals concentrations in air-borne samples with the addition of $20 \mathrm{mgO} \cdot \mathrm{dm}^{-3}$ with ozone-free aerobic results, the concentration of metals was reduced from $8 \%$ (for $\mathrm{Zn}$ and $\mathrm{Cu}$ ) to 27\% (for $\mathrm{Cd}$ ).

Compost produced from biodegradable waste is characterized by small concentrations of toxic metals - especially cadmium and chromium (Table 1). Compared to the compost obtained in professional municipal waste installations, concentrations of toxic metals were reduced by $5 \div 10$ times [Lima et al. 2004, Madrid et al. 2007, Puglisi et al. 2007, Ciesielczuk and Kusza 2009].

By analyzing the data presented in Table 2, the positive effects of the use of ozone on the stabilization process of compost can be shown. The addition of ozone to the air during stabilization

Table 1. The average content of heavy metals in the examined compost along with a standard deviation $\left[\mathrm{mg} \cdot \mathrm{kg}_{\mathrm{dw}}{ }^{-1}\right]$

\begin{tabular}{|c|c|c|c|c|}
\hline \multirow{2}{*}{ Toxic metal } & \multicolumn{3}{|c|}{$\begin{array}{l}\text { Ozone content in the air } \\
{\left[\mathrm{mg} \cdot \mathrm{dm}^{-3}\right]}\end{array}$} & \multirow{2}{*}{$\begin{array}{l}\text { Acceptable content of toxic metals } \\
\text { for organic fertilizers acc. Dz. U. } 2009 \\
\text { No. 224, item. } 1804\end{array}$} \\
\hline & 0 & 10 & 20 & \\
\hline $\mathrm{Pb}$ & $26.19 \pm 0.17$ & $23.57 \pm 0.33$ & $22.04 \pm 0.29$ & 140 \\
\hline $\mathrm{Cd}$ & $1.06 \pm 0.02$ & $0.93 \pm 0.07$ & $0.77 \pm 0.08$ & 5 \\
\hline $\mathrm{Ni}$ & $9.81 \pm 0.11$ & $9.23 \pm 0.09$ & $8.45 \pm 0.15$ & 60 \\
\hline $\mathrm{Zn}$ & $190.74 \pm 6.38$ & $185.98 \pm 9.21$ & $174.08 \pm 7.03$ & - \\
\hline $\mathrm{Cr}$ & $3.49 \pm 0.71$ & $3.26 \pm 0.4$ & $3.1 \pm 0.59$ & 100 \\
\hline $\mathrm{Cu}$ & $60.8 \pm 2.93$ & $58.27 \pm 6.09$ & $55.69 \pm 4.62$ & - \\
\hline
\end{tabular}


Table 2. Average value of AT4 and humidity in the tested compost.

\begin{tabular}{|c|c|c|c|}
\hline \multirow{2}{*}{ Parameter } & \multicolumn{3}{|c|}{$\begin{array}{c}\text { Ozone content in the air } \\
{\left[\mathrm{mg} \cdot \mathrm{dm}^{-3}\right]}\end{array}$} \\
\cline { 2 - 4 } & 0 & 10 & 20 \\
\hline Humidity $[\%]$ & $28.62 \pm 2.53$ & $22.49 \pm 2.18$ & $18.03 \pm 1.94$ \\
\hline AT4 $\left[\mathrm{mgO}_{2} \cdot \mathrm{g}_{\mathrm{dw}}{ }^{-1}\right]$ & $12.06 \pm 1.13$ & $9.53 \pm 0.88$ & $8.72 \pm 0.92$ \\
\hline
\end{tabular}

had a positive effect on the moisture content of the stabilizer in the range $22 \div 37 \%$. Blank test (0 $\mathrm{mgO}_{3} \cdot \mathrm{dm}^{-3}$ ) does not meet the regulatory requirements for mature composts (AT4 indicator above $\left.10 \mathrm{mgO}_{2} \cdot \mathrm{g}_{\mathrm{dw}}{ }^{-1}\right)$. The use of ozone at the start of the stabilization phase resulted in a reduction in aerobic activity of compost from 21 to $28 \%$.

\section{CONCLUSIONS}

Experimental experience has shown a positive effect of ozone on the reduction of toxic metals $\mathrm{Pb}, \mathrm{Cd}, \mathrm{Ni}, \mathrm{Zn}, \mathrm{Cr}, \mathrm{Cu}-$ in the obtained stabilized compost to $30 \%$ of the base value. The research has shown the significant effect of ozone on the quality parameters of the resulting compost. In both anaerobic analyzes $\left(10 \mathrm{mgO}_{3} \cdot \mathrm{dm}^{-3}\right.$ and $\left.20 \mathrm{mgO}_{3} \cdot \mathrm{dm}^{-3}\right)$, a decrease in the stabilized compost humidity up to $40 \%$ and an oxygen activity up to $30 \%$ in relation to the aerobic sample without ozone.

\section{Acknowledgements}

Publication was financed by the Ministry of Science and Higher Education of the Republic of Poland - statutory activity no. BM-4637 and DS3600/WIPiE/2017.

\section{REFERENCES}

1. Amin M. M., Moazzam M. M. A. 2014. Advanced oxidation treatment of composting leachate of municipal solid waste by ozone-hydrogen peroxide. International Journal of Environmental Health Engineering, 3(1), 24-29, DOI: 10.4103/2277-9183.138415.

2. Benlboukht F., Lemee L., Amir S., Ambles A., Hafidi M. 2016. Biotransformation of organic matter during composting of solid wastes from traditional tanneries by thermochemolysis coupled with gas chromatography and mass spectrometry. Ecological Engineering, 90, 87-95.

3. Bundesministeriumfür Land- und Forstwirtschaft, Umwelt und Wasserwirstchaft. Wien, 2002.
4. Ciesielczuk T., Kusza G. 2009. Heavy metal assessment in solid municipal wastes composts as aborder for fertilizing use. OchronaŚrodowiska i ZasobówNaturalnych, 41, 347-354.

5. Fernández C., Mateu C., Moral R., Francina Sole-Mauri, Sole-Mauri F. 2016. A predictor model for the composting process on an industrial scale based on Markov processes. Environmental Modelling \& Software, 79, 156-166.

6. Ghisellini P., Cialani C., Ulgiati S. 2016. A review on circular economy: the expected transition to a balanced interplay of environmental and economic systems. Journal of Cleaner Production, 114, 11-32.

7. Grzesik K., Malinowski M. 2016. Life cycle assessment of refuse-derived fuel production from mixed municipal waste. Energy Sources, Part A: Recovery, Utilization, and Environmental Effects, 38(21), 3150-3157, DOI: 10.1080/15567036.2015.1136976.

8. Gutierez M. C., Martin M. A., Serrano A., Chica A. F. 2015. Monitoring of pile composting process of OFMSW at full scale and evaluation of odour emission impact. Journal of Environmental Management, 151, 531-539.

9. Hurka M., Malinowski M. 2014. Assessment of the use of EWA bioreactor in the process of bio-drying of undersize fraction manufactured from mixed municipal solid waste. Infrastructure and ecology of rural areas, IV/1/2014, 1127-1136, DOI: 10.14597/infraeco.2014.4.1.083.

10. Jinyi G., Guangqun H., Jing H., Jianfei Z., Lujia H. 2016. Manure-wheat straw composting: A new approach that considers surface convection. International Journal of Heat and Mass Transfer, 97, 735-741.

11. Junya Z., Meixue Ch., Qianwen S., Juan T., Chao J., Xueting L., Yuxiu Z., Yuansong W. 2016. Impacts of addition of natural zeolite or a nitrification inhibitor on antibiotic resistance genes during sludge composting. Water Research, 91, 339-349.

12. Kasiński S., Wojnowks-Baryla I. 2014. Oxygen demand for the stabilization of the organic fraction of municipal solid waste in passively aerated bioreactors. Waste Management, 34(2), 316-322.

13. Lebrero R., Rodríguez E., García-Encina P. A., Muñoz R. 2011. A comparative assessment of biofiltration and activated sludge diffusion for odour abatement. Journal of Hazardous Materials, 190(1-3), 622-630. 
14. Lian Y., Shihua Z., Zhigiang Ch., Qinxue W., Yao W. 2016. Maturity and security assessment of pilot-scale aerobic co-composting of penicillin fermentation dregs (PFDs) with sewage sludge. Bioresource Technology, 204, 185-191.

15. Lima J.S., DeQueiroz J.E.G., Freitas H.B. 2004. Effect of selected and non-selected urban waste compost on the initial growth of corn. Resources, Conservation and Recycling, 42, 309-315.

16. Madrid F., Lopez R., Cabrera F. 2007. Metal accumulation in soil after application of municipal solid waste compost under intensive farming conditions. Agriculture, Ecosystems and Environment, 119, 249-256.

17. Mokhtarani N., Nasiri A, Ganjidoust H., Yasrobi S. Y. 2014. Post-treatment of composting leachate by ozonation. The Journal of the International Ozone Association, 36(6), 540-548, DOI: 10.1080/01919512.2014.904737.

18. Morales A. B., Bustamante M. A., MarhuendaEgea F. C., Moral R., Ros M., Pascual J. A. 2016. Agri-food sludge management using different cocomposting strategies: study of the added value of the composts obtained. Journal of Cleaner Production, 121, 186-197.

19. Mukesh K. A., Akhilesh K. P., Pushpendra S. B., Wong W.C., Li R., Zengqiang Z. 2016. Co-composting of gelatin industry sludge combined with organic fraction of municipal solid waste and poultry waste employing zeolite mixed with enriched nitrifying bacterial consortium. Bioresource Technology, Available online 11 February.

20. PN-EN 15169:2007. Charakteryzowanie odpadów - Obliczanie suchej masy po oznaczaniu suchej pozostałości strat lub zawartości wody.

21. PN-EN 13657:2006. Charakteryzowanie odpadów. Roztwarzanie do dalszego oznaczania części pierwiastków rozpuszczalnych w wodzie królewskiej.

22. Puglisi E., Cappa F., Fragoulis G., Trevisan M., Re A.A.M. 2007. Bioavailability and degradation of phenanthrene in compost amended soils. Chemosphere 67: 548-556.
23. Rotametr. 2012. Reaktor do kompostowania - typ BKB 100. Instrukcjaobsługi. Gliwice, ss. 8.

24. Rozporządzenie Ministra Rolnictwa i Rozwoju Wsi z dnia 18 czerwca 2008 r. w sprawie wykonania niektórych przepisów ustawy o nawozach i nawożeniu (Dz. U. 2008 nr 119, poz. 765)

25. Siles J. A., Vargas F., Gutiérrez M. C., Chica A. F., Martín M.A. 2016. Integral valorisation of waste orange peel using combustion, biomethanisation and co-composting technologies. Bioresource Technology, Vol. 211, 173-182.

26. Ustawa o nawozach i nawożeniu (Dz. U. $2007 \mathrm{nr}$ 147, poz. 1033).

27. Ustawa o odpadach (Dz. U. 2013 poz. 21).

28. Vandecasteele B., Sinicco T., D’Hose T., Vanden Nest T., Mondini C. 2016. Biochar amendment before or after composting affects compost quality and $\mathrm{N}$ losses, but not P plant uptake. Journal of Environmental Management, Vol. 168, 200-209.

29. Wytyczne dotyczące wymagań dla procesów kompostowania, fermentacji i mechaniczno-biologicznego przetwarzania odpadów. 2008. MinisterstwoŚrodowiska, DepartamentGospodarkiOdpadami, Warszawa, ss. 35.

30. Yongjiang W., Li P., Xinyu L., Yuansheng W., Kexun Z., Fei L. 2016. Using thermal balance model to determine optimal reactor volume and insulation material needed in a laboratory-scale composting reactor. Bioresource Technology, Vol. 206, 164-172.

31. Yuan J., Yang Q., Zhang Z., Li G., Luo W., Zhang D. 2015.Use of additive and pretreatment to control odors in municipal kitchen waste during aerobic composting. Journal of Environmental Sciences, Vol. 37, 83-90.

32. Yuquan W., Zimin W., Zhenyu C., Yue Z., Xinyu Z., Qian L., Xueqin W., Xu Z. 2016. A regulating method for the distribution of phosphorus fractions based on environmental parameters related to the key phosphate-solubilizing bacteria during composting. Bioresource Technology, Vol. 211, 610-617. 